\title{
UJI EKSPERIMENTAL PENGGUNAAN JENIS ELEKTRODA LAS TERHADAP LAJU KOROSI BAJA ASTM A36
}

\author{
Muhammad Sihabudin *, Helmy Purwanto, Muhammad Dzulfikar \\ Jurusan Teknik Mesin, Fakultas Teknik, Universitas Wahid Hasyim \\ Jl. Menoreh Tengah X/22, Sampangan, Semarang 50236. \\ *Email:Sihabudin_sahlyleny@gmail.com
}

\begin{abstract}
Abstrak
Proses pengelasan pada konstruksi mesin dan bangunan mempunyai kecenderungan untuk mengalami korosi. Pemilihan material dan elektroda saat proses penyambungan logam memberikan kontribusi sangat penting dalam pencegahan terjadinya korosi. Elektroda atau kawat las yang sesuai dengan spesifikasi logam las juga berpengaruh untuk memperkecil peluang terjadinya korosi. Penelitian ini bertujuan untuk menganalisis pengaruh berbagai jenis elektroda yang digunakan dalam pengelasan baja karbon rendah serta pengaruh bentuk fluida korosif terhadap laju korosi serta jenis korosi yang terbentuk akibat proses tersebut. Penelitian dilakukan menggunakan material baja mild steel A36, dengan pengelasan menggunakan elektroda las elektroda las E7016, E7018 dan E8016. Uji korosi dilakukan dengan pemodelan fluida celup dan mangalir dalam larutan hidro klorida (HCl) selama 10, 20, dan 30 menit dengan diberi perlakuan las menggunakan flux. Hasil penelitian diperoleh bahwa semakin lama perendaman akan semakin bertambah besar laju korosi baja. Perhitungan laju korosi ini dihitung dengan metode pengurangan berat. Percobaan pengkorosian dalam keadaan berputar/mengalir mendapatkan nilai laju korosi yang paling besar adalah 1,08 mm/tahun dengan elektroda las E8016 dan waktu pencelupan 30 menit. Pada baja yang di las menggunakan elektroda E8016 yang di celup (putar) selama 30 menit terjadi korosi erosi dan korosi sumur.
\end{abstract}

Kata kunci : Baja karbon rendah, elektroda, laju korosi.

\section{PENDAHULUAN}

Baja karbon rendah (low carbon steel) adalah material yang banyak digunakan untuk konstruksi umum. karena baja karbon rendah mempunyai keuletan yang tinggi, tetapi kekerasannya rendah dan tidak tahan aus. Baja karbon rendah merupakan logam yang mudah terserang oleh korosi, seperti halnya baja mild steel. Baja karbon rendah (mild steel) sangat banyak penggunannya salah satunya sebagai bahan pembuatan lembaran plat atau yang dinamakan plat baja. Selain karena kekerasannya relatif rendah, lunak dan keuletannya tinggi, baja ini juga mudah untuk dilakukan pengelasan (Hestyawan, 2011).

Teknologi pengelasan saat ini banyak digunakan untuk membangun jembatan dan memperbaiki kerusakan yang terjadi pada jembatan. Kerusakan dapat berupa retakan atau korosi dimana dalam keadaan memaksa atau situasi darurat harus dilakukan perbaikan dengan menggunakan teknologi pengelasan. Metode yang lazim digunakan adalah SMAW (Shielded Metal Arc Welding).

Lingkungan air yang korosif juga dapat menyebabkan berkurangnya kekuatan dan mengakibatkan kerusakan. Kerusakan tersebut bisa disebabkan oleh bermacammacam penyebabnya dan salah satunya adalah korosi. Korosi bisa diakibatkan karena struktur terendam di dalam air. (Pranata \& Supomo, 2013).

Korosi tidak pernah berhenti, (Threthewey \& Chamberlain, 1991) menyatakan bahwa korosi merupakan kerusakan material yang disebabkan oleh pengaruh lingkungan sekelilingnya. Adapun proses korosi yang terjadi disamping oleh reaksi kimia, juga diakibatkan oleh proses elektrokimia yang melibatkan perpindahan elektron-elektron, dari reduksi ion logam maupun pengendapan logam dari lingkungan sekeliling. Lingkungan sekelilingnya dapat berupa lingkungan asam, udara, embun, air laut, air danau, air sungai. Salah satu faktor yang mempengarui terjadinya korosi dalam 
lingkungan air adalah keberadaan elektrolit. Contohnya adalah asam sulfat, senyawa ini merupakan elektrolit terkuat.

Tujuan penelitian ini adalah untuk Mengetahui dan menganalisa pengaruh media pengkorosi $\mathrm{HCl}$ terhadap laju korosi pada baja mild steel A36 yang diberi perlakuan pengelasan dengan elektroda las yang berbeda dengan metode celup (diam) dan celup (putar)/ mengalir (Anggaretno dkk., 2012). Penelitian ini menggunakan plat baja mild steel A36 dengan perlakuan pengelasan 3 variasi flux elektroda pada plat mild steel A36 menggunakan larutan $\mathrm{HCl}$ dengan konsentrasi $16 \%$ dengan kondisi air diam dan air dalam kondisi mengalir.

\section{METODE PENELITIAN}

Uji komposisi dilakukan untuk mengetahui komposisi kimia yang terkandung dalam baja karbon rendah ASTM A36 yang nantinya akan digunakan untuk bahan pengujian. Proses pengujian komposisi ini dilakukan di laboratorium Politeknik Manufaktur Ceper, klaten, jawa tengah. Hasil dari pengujian ini yaitu untuk mengetahui seberapa besar unsur-unsur bahan yang terkandung seperti karbon, mangan, silicon, sulfur, fosfor, dan unsurunsur lainnya.

Proses Pembuatan Spesimen menggunakan material plat baja ASTM A36. Proses pengelasan menggunakan 3 elektroda, yaitu E7018, E7016 dan E8016. Pada proses ini spesimen dibagi menjadi 3 bagian dengan ukuran panjang $50 \mathrm{~mm}$, lebar $100 \mathrm{~mm}$ seperti terlihat pada gambar 1.

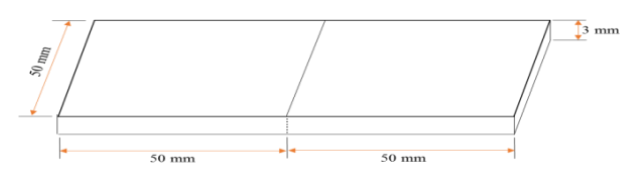

\section{Gambar 1. Bentuk dan ukuran spesimen plat ASTM A36}

Penelitian dilakukan di Laboratorium Material, Fakultas Teknik, Universitas Wahid Hasyim Semarang. Spesimen yang telah dilakukan proses pengelasan selanjutnya dibersihkan dari kotoran-kotoran dan sisa karat yang menempel pada spesimen. Pengujian laju korosi dilakukan dengan metode immersion test atau pencelupan dan dengan metode putar kedalam larutan korosif dengan berbagai parameter operasi yang disesuai kan untuk mendekati kondisi nyata dilapangan. Larutan korosif yang digunakan dalam penelitian ini adalah larutan $\mathrm{HCl}$ dengan konsentrasi $16 \%$ dengan berbagai macam variasi waktu. Untuk mengetahui tingkat korosi pada plat baja ASTM A36 maka pada penelitian ini menggunakan media larutan korosif $\mathrm{HCl}$ dengan konsentrasi sebesar $16 \%$ dengan variasi perendaman selama 10 menit, 20 menit, dan 30 menit.

Tahapan selanjutnya adalah pengukuran berat dari spesimen uji. Pada tahap penimbangan, dan dilanjutkan dengan pemodelan media korosi $\mathrm{HCl}$ dengan konsentrasi $16 \%$. Larutan $\mathrm{HCl}$ sebanyak 5 liter dicampur dengan 5 liter aquades dan direndam menggunakan 3 variasi waktu yaitu 10, 20, dan 30 menit. Setelah dilakukan proses korosif kemudian dilanjtukan penimbangan berat akhir

\section{HASIL DAN PEMBAHASAN}

Hasil pengujian pengujian dengan metode rendam (celup) ditunjukkan pada tabel 1. menunjukkan bahwa variasi waktu perendaman pada spesimen yang di las menggunakan elektroda E7016, E7018 dan E8016 mempengaruhi laju korosi pada logam las. Dalam penelitian ini, variasi waktu yang digunakan adalah 10 menit, 20 menit dan 30 menit. Variasi flux elektroda pada pengelasan yang mempengaruhi laju korosi pada logam las. Dalam penelitian ini, variasi pengujian dengan metode rendam dan metode putar. Flux elektroda yang yang digunakan adalah E7016, E7018 dan E8016.

Pada Tabel 1. menunjukan hasil besarnya laju korosi pada baja ASTM A36 yang di las menggunakan elektroda E7016, E7018 dan E8016, dengan metode pengujian larutan pengkorosinya yaitu $\mathrm{HCl}$ $16 \%$ dalam keadaan diam. Pada Pada pengujian ini diperoleh data bahwa laju korosi yang di dapat pada waktu pencelupan 10 menit dengan elektroda las 
E7016 adalah 73,23 mm/tahun dan pada waktu 20 menit dengan elektroda las E7016 laju korosinya adalah sebesar 74,07 $\mathrm{mm} /$ tahun, sedangkan pada variasi elektroda las E7016 dengan waktu perendaman 30 menit mengalami laju korosi sebesar 155,26 mm/tahun.

Tabel 1. perubahan berat metode rendam

\begin{tabular}{cccccc}
\hline HCl & $\begin{array}{c}\text { Elektroda } \\
\text { las }\end{array}$ & $\begin{array}{c}\text { Waktu } \\
\text { (menit) }\end{array}$ & $\begin{array}{c}\text { W 1 } \\
\text { (gram) }\end{array}$ & $\begin{array}{c}\text { W2 } \\
\text { (gram) }\end{array}$ & $\begin{array}{c}\text { CR } \\
\text { Laju Korosi } \\
\text { (mm/tahun) }\end{array}$ \\
\hline & tanpa las & & 114,06 & 113,79 & 73,23 \\
$16 \%$ & E 7016 & 0,167 & 122,41 & 122,01 & 134,27 \\
& E 7018 & & 124,04 & 123,57 & 128,17 \\
& E 8016 & & 117,52 & 117,21 & 140,37 \\
& tanpa las & & 113,52 & 112,94 & 48,97 \\
& E 7016 & 0,333 & 121,6 & 120,85 & 74,07 \\
& E 7018 & & 123,06 & 122,39 & 76,21 \\
& E 8016 & & 116,84 & 116,18 & 80,19 \\
& tanpa las & & 112,91 & 112,08 & 83,58 \\
& E 7016 & 0,5 & 121,28 & 119,81 & 155,26 \\
& E 7018 & 122,82 & 121,3 & 173,06 \\
& E 8016 & & 116,48 & 115,43 & 220,56 \\
\hline
\end{tabular}

Pemodelan korosi dalam keadaan diam mendapatkan nilai laju korosi yang paling besar adalah 155,26 $\mathrm{mm} /$ tahun., dengan elektroda las E7018 dan waktu pencelupan 30 menit di karenakan kandungan lapisan dari fluks elektroda itu. Untuk lebih jelasnya bisa dilihat dalam bentuk grafik hasil uji korosi dengan media pengkorosi dalam keadaan celup diam pada Gambar 2.

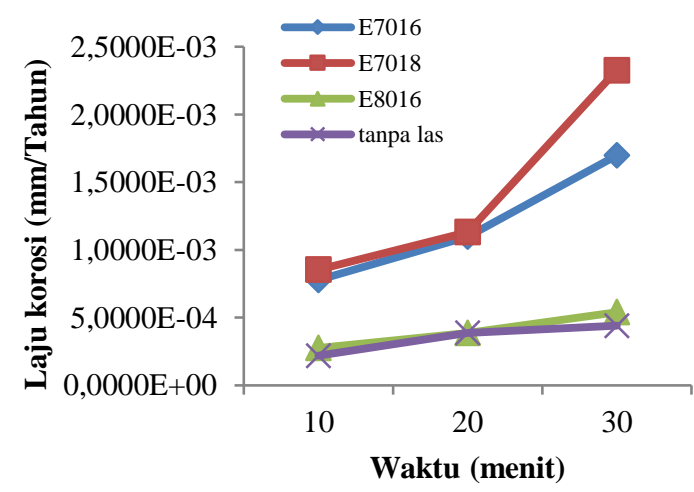

Gambar 2. laju korosi media celup
Berdasarkan gambar 2 dapat dilihat tingkat pengurangan berat spesimen saat uji rendam dengan $\mathrm{HCl}$ konsentrasi 16\% terlihat jelas laju korosi terbesar terjadi pada waktu 30 menit perendaman, dan terjadi pada spesimen dengan flux elektroda las E7018 besarnya laju korosi 155,26 mm/tahun kemudian elektroda E7016, dan E8018 serta tanpa pengelasan. Untuk waktu 20 menit, laju korosi terbesar terjadi pada flux elektroda E7016 dengan laju korosi sebesar $74,07 \mathrm{~mm} /$ tahun. Sedangkan untuk waktu 10 menit laju korosi terbesarnya adalah $76,21 \mathrm{~mm} /$ tahun,. terjadi pada spesimen dengan elektroda las E7018.

Hasil pengujian pengujian dengan metode keadaan berputar/mengalir ditunjukkan pada tabel 4.3 menunjukkan bahwa variasi waktu perendaman pada spesimen yang di las menggunakan elektroda E7016, E7018 dan E8016 mempengaruhi laju korosi pada logam las.

Tabel 2. Hasil pengujian laju korosi metode celup dengan larutan pengkorosi asam klorida $\mathrm{HCl} 16 \%$ dalam keadaan berputar/mengalir.

\begin{tabular}{cccccc}
\hline HCl & $\begin{array}{c}\text { Jenis } \\
\text { elektroda }\end{array}$ & $\begin{array}{c}\text { Waktu } \\
\text { (menit) }\end{array}$ & $\begin{array}{c}\mathbf{W}_{\mathbf{1}} \\
(\text { gram })\end{array}$ & $\begin{array}{c}\mathbf{w}_{\mathbf{2}} \\
\text { (gram) }\end{array}$ & $\begin{array}{c}\text { CR } \\
\text { Laju Korosi } \\
\text { (mm/tahun) }\end{array}$ \\
\hline $16 \%$ & tanpa las & & 116,03 & 115,91 & 163,9 \\
& E 7016 & 10 & 115,92 & 115,7 & 236,75 \\
& E 7018 & & 119,28 & 119,07 & 283,49 \\
& E 8016 & & 119,91 & 119,68 & 188,18 \\
& tanpa las & & 115,88 & 115,72 & 176,57 \\
& E 7016 & 20 & 115,49 & 115,25 & 228,32 \\
& E 7018 & & 118,90 & 118,65 & 203,97 \\
& E 8016 & & 119,03 & 118,77 & 200,92 \\
& tanpa las & & 115,49 & 115,08 & 168,28 \\
& E 7016 & 30 & 115,14 & 114,37 & 298,05 \\
& E 7018 & & 118,56 & 117,71 & 308,18 \\
& E 8016 & & 118,64 & 117,56 & 212,89 \\
\hline
\end{tabular}

Pada Tabel 2. menunjukan hasil besarnya laju korosi pada baja ASTM A36 yang di las menggunakan elektroda E7016, E7018 dan E8016, dengan metode pengujian larutan pengkorosinya yaitu $\mathrm{HCl}$ $16 \%$ dalam keadaan berputar/mengalir. Pada pengujian ini diperoleh data bahwa 
laju korosi yang di dapat pada waktu pencelupan 10 menit dengan elektroda las E7016 adalah $236,75 \mathrm{~mm} / \mathrm{tahun}$, dan pada waktu 20 menit dengan elektroda las E7016 laju korosinya adalah sebesar 228,32 $\mathrm{mm} /$ tahun. Sedangkan pada variasi elektroda las E7016 dengan waktu perendaman 30 menit mengalami laju korosi sebesar 298,05 mm/tahun. Semakin lama waktu pencelupan, semakin tinggi pula laju korosinya.

Pada waktu pencelupan 10 menit dengan elektroda las E7018 adalah 283,49 $\mathrm{mm} / \mathrm{tahun}$, dan pada waktu 20 menit dengan elektroda las E7018 laju korosinya adalah sebesar 203,97 mm/tahun, sedangkan pada variasi elektroda las E7018 dengan waktu perendaman 30 menit mengalami laju korosi sebesar $308,18 \mathrm{~mm} /$ tahun. Pada waktu pencelupan 10 menit dengan elektroda las E8016 adalah 188,18 mm/tahun dan pada waktu 20 menit dengan elektroda las E8016 laju korosinya adalah sebesar, 200,92 $\mathrm{mm} /$ tahun sedangkan pada variasi elektroda las E8016 dengan waktu perendaman 30 menit mengalami laju korosi sebesar 212,89 mm/tahun.

Percobaan pengkorosian dalam keadaan berputar mendapatkan nilai laju korosi yang paling besar adalah 212,89 $\mathrm{mm} /$ tahun dengan elektroda las E8016 dan waktu pencelupan 30 menit.Untuk lebih jelasnya bisa dilihat dalam bentuk grafik hasil uji korosi dengan media pengkorosi dalam keadaan celup diam pada Gambar 3.

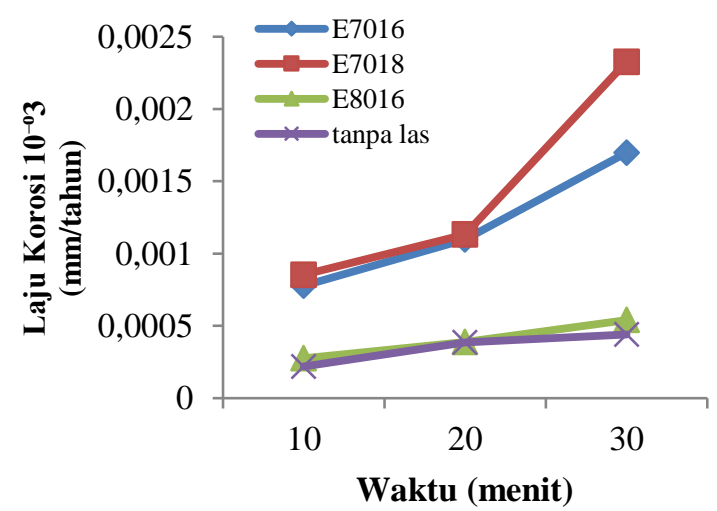

Gambar 3. laju korosi keadaan berputar atau mengalir.
Berdasarkan data dan diagram menjelaskan bahwa laju korosi terbesar terjadi pada 30 menit waktu perendaman berputar. Untuk perendaman berputar dalam larutan $\mathrm{HCl}$ konsentrasi $16 \%$ laju korosi terbesarnya adalah 308,18 $\mathrm{mm} /$ tahun sedangkan untuk laju korosi terkecil sebesar 212,18 mm/tahun dengan waktu perendaman selama 20 menit.

Berdasarkan data dan Gambar 4. semakin lama perendaman laju korosi akan semakin naik dan laju korosi terbesar terjadi diawal proses perendaman, yaitu pada setelah 10 menit pada variasi waktu perendaman. Perbedaan laju korosi tersebut di pengaruhi tensile strenght pada elektroda dan baja yang di las. Selisih unsur mangan (Mn) pada baja dan elektroda las juga mempengaruhi laju korosi pada baja. Secara morfologi permukaan weldmetal dengan laju korosi paling tinggi, permukaannya terlihat lebih kasar.

Pada metode celup (putar) / mengalir terjadi korosi erosi dan korosi sumur seperti yang ditunjukkan Gambar 5. dan Gambar 6. sebagai berikut :

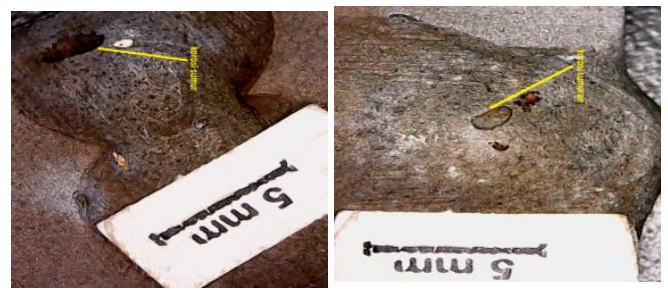

\section{Gambar 4. korosi sumur (pitting corrosion)}

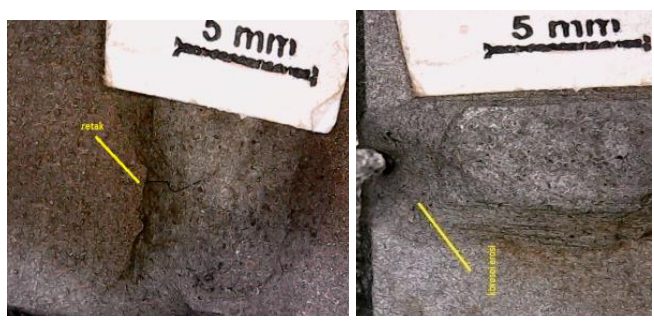

\section{Gambar 5. Korosi erosi (errosion corrosion)}

Kecepatan aliran fluida berpengaruh terhadap laju korosi, karena mempengaruhi pertukaran ion dan elektron 
di permukaan logam. Fluida yang mengalir dengan lambat atau stagnat, dapat mengakibatkan korosi setempat. Bila fluida bersifat agresif dan mempunyai kecepatan yang cukup, maka dapat terjadi korosi erosi (errosion corrosion), seperti yang diperlihatkan pada Gambar 5. Korosi erosi (errosion corrosion) terjadi karena keausan dan menimbulkan bagian-bagian yang tajam dan kasar, bagian-bagian inilah yang mudah terjadi korosi dan juga diakibatkan karena fluida yang sangat deras dan dapat mengikis film pelindung pada logam . Semakin tinggi kecepatan fluida, maka faktor kerusakan mekanik menjadi dominan. Korosi erosi inilah yang menyebabkan terjadinya retak diantara logam dan sambungan las.

Pada metode celup putar juga terjadi korosi sumur (pitting corrosion), korosi sumur (pitting corrosion) adalah korosi yang disebabkan karena komposisi logam yang tidak homogen yang dimana pada daerah batas timbul korosi yang berbentuk sumur seperti byang di tunjukkan Gambar 4.

\section{Perbandingan Laju Korosi Metode Celup Diam Dengan Metode Celup Putar/ Mengalir}

Data hasil perbandingan pengujian laju korosi pada baja karbon rendah ASTM A36 dengan media pengkorosi $\mathrm{HCl} 16 \%$ menggunakan metode celup diam dengan metode celup putar atau mengalir dapat dilihat pada Gambar 6 .

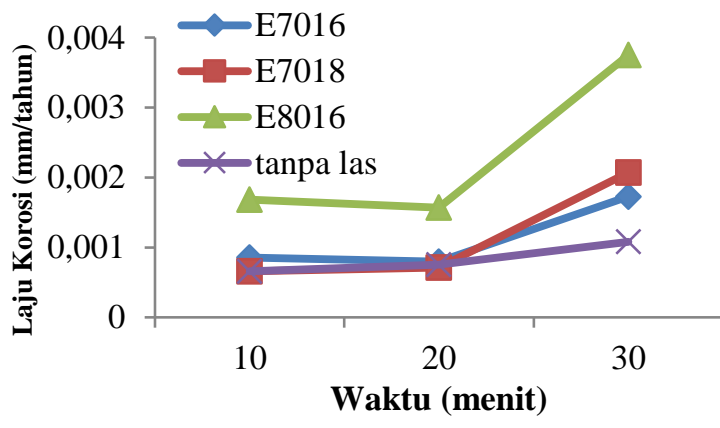

\section{Gambar 6. laju korosi celup diam dan metode celup putar/ mengalir.}

Perbandingan laju korosi pada baja karbon rendah mild steel ASTM A36 dengan menggunakan metode celup diam dan metode celup putar/ mengalir, berdasarkan dari hasil data pengujian seperti pada Gambar 7. menunjukan bahwa terdapat perbedaan rata-rata laju korosi pada ke dua metode tersebut. Percobaan dengan metode celup putar/ mengalir hasil laju korosinya sangat meningkat sedangkan pada metode celup diam nilai rata-rata laju korosinya menurun atau lebih kecil jika dibandingkan dengan metode celup putar/ mengalir. Pada metode celup putar/mengalir laju korosinya meningkat yaitu pada percobaan pencelupan menit pertama 10 menit, sedangkan pada pencelupan menit 20 laju korosinya naik akan tetapi nilai kenaikannya tidak terlalu besar jika dibandingkan dengan pencelupan 30 menit dikarenakan kondisi pengeringan yang berbeda. Pengeringan dilakukan pada sekitar pukul 15.00 sampai 15.15, karena suhu pengeringan itu, menjadikan kadar air dalam spesimen baja lebih banyak di banding pengeringan pada sekitar pukul 12.00. dan kondisi suhu itu juga berpengaruh terhadap laju korosi, semakin tinggi suhu pengeringan, semakin tinggi pula laju korosinya.

Pada waktu pencelupan 30 menit nilai laju korosinya lebih besar dibanding 10 menit dan 20 menit. Laju korosi terbesar pada metode celup putar/ mengalir terdapat pada E8016 dengan waktu pencelupan 30 menit, ini di pengaruhi tensile strenght pada flux elektroda dan baja yang di las. Apabila baja tersebut dilas menggunakan elektroda yang memiliki nilai tensile strenght lebih rendah dari nilai tensile strenght baja tersebut, maka nilai rata-rata korosinya akan semakin tinggi dan bagitu juga sebaliknya. Selisih unsur mangan (Mn) pada baja dan elektroda las juga mempengaruhi perbedaan laju korosi pada baja. (Rochani Imam, 2012).

\section{PENUTUP}

\section{Kesimpulan}

Dari hasil penelitian dan pembahasan yang telah dilakukan dapat disimpulkan bahwa

1. Pengaruh media pengkorosi $\mathrm{HCl}$ terhadap laju korosi pada baja mild steel A36 yang diberi perlakuan pengelasan dengan elektroda las 
yang berbeda yaitu waktu sangat berpengaruh, dengan bertambahnya waktu pencelupan beban yang hilang (weight loss) semakin bertambah. Laju korosi paling rendah terjadi pada elektroda E7016 pada pencelupan diam selama 10 menit.

2. Pengaruh aliran media pengkorosi $\mathrm{HCl}$ terhadap laju korosi pada baja mild steel A36 yang diberi perlakuan pengelasan dengan elektroda las yang berbeda yaitu percobaan pengkorosian dalam keadaan berputar/mengalir mendapatkan nilai laju korosi yang paling besar pada elektroda las E8016 dan waktu pencelupan 30 menit.

\section{DAFTAR PUSTAKA}

Anggaretno, G., Rochani, I., \& Supomo, H.

(2012). Analisa pengaruh jenis

elektroda terhadap laju korosi pada pengelasan pipa API 5L grade X65 dengan media korosi $\mathrm{FeCl} 3$. Jurnal teknik ITS.

http://ejurnal.its.ac.id/index.php/tekni k/article/view/1619

Hestyawan. (2011). Klasifikasi Logam dan Paduannya $\mid$ Afterlife $\mid$.

https://romzneverdie.wordpress.com/ metallurgy/klasifikasi-logam-danpaduannya/

Pranata, S. A., \& Supomo, H. (2013). Analisa Perbandingan Laju Korosi Pada Pengelasan di Bawah Air karena Pengaruh Variasi Jenis Pelindung Flux Elektroda. Jurnal Teknik ITS, 2(1), G100-G105.

Threthewey, K. R., \& Chamberlain, J. (1991). Korosi untuk mahasiswa sains dan Rekayasa. In PT. Gramedia Pustaka Utama, Jakarta. 